\title{
Late Quaternary stratigraphic development in the lower Luni, Mahi and Sabarmati river basins, western India
}

\author{
M JAIN ${ }^{1}, \mathrm{~S}$ K TANDON ${ }^{2}$ and S C BHATT ${ }^{3}$ \\ ${ }^{1}$ Risoe National Laboratory, DK-4000 Roskilde, Denmark. \\ ${ }^{2}$ Department of Geology, Delhi University, Delhi - 110 00\%, India. \\ ${ }^{3}$ Department of Geology, Bundelkhand University, Jhansi, UP, India. \\ ${ }^{1}$ email: mgj@aber.ac.uk
}

This study reviews the Quaternary alluvial stratigraphy in three semi-arid river basins of western India i.e., lower Luni (Rajasthan), and Mahi and Sabarmati (Gujarat alluvial plains). On the basis of OSL chronologies, it is shown that the existing intra-valley lithostratigraphic correlations require a revision. The sand, gravel and mud facies are present during various times in the three basins, however, the fluvial response to climate change, and the resulting facies associations, was different in the Thar desert as compared to that at the desert margin; this makes purely lithostratigraphic correlations unviable. It is further shown that the rivers in the Thar desert were more sensitive to climate change and had small response times and geomorphic thresholds as compared to the desert-margin rivers. This is illustrated during the early OIS 1, when the Luni river in the Thar desert was dynamic and showed frequent variations in fluvial styles such as gravel bedload braided streams, sand-bed ephemeral streams and meandering streams, all followed by incision during the early Holocene. The coeval deposits in Sabarmati, however, only show a meandering, floodplaindominated river.

Late Quaternary alluvial deposits in these basins unconformably overlie some older deposits that lack any absolute chronology. Based on the facies types and their associations, and the composition and architecture of the multistoried gravel sheets in the studied sections, it is suggested that older deposits are of pre-Quaternary age. This hypothesis implies the presence of a large hiatus incorporating much of the Quaternary period in the exposed sections.

\section{Introduction}

Significant accumulation of continental sedimentary facies occurred during the Neogene and Quaternary in the lower Luni basin in the Thar desert and the Sabarmati and Mahi basins along the southern margin of the desert (Merh and Chamyal 1997; Bajpai et al 2001). A significant proportion of these deposits occurs in the sub-surface in the structural depressions related to continental margin rifting and graben formation (Maurya et al 1995; Bajpai et al 2001). Previous work on these alluvial deposits include stratigraphic, sedimentological, tectonic and chronological studies
(Pant and Chamyal 1990; Merh and Chamyal 1997 and references therein; Tandon et al 1997; Jain et al 1999; Kar et al 2000; Maurya et al 2000; Juyal et al 2000; Srivastava et al 2001; Chamyal et al 2003; Jain and Tandon, 2003a; Jain et al 2004). Evidence of palaeoclimate and/or sea-level change during the late Pleistocene and Holocene have been recorded from Rajasthan and Gujarat (Singh et al 1974; Bryson and Swain 1981; Swain et al 1983; Pant and Juyal, 1993; Juyal et al 1995; Prasad et al 1997, 1998; Andrews et al 1998; Rachna et al 1998; Prasad and Gupta, 1999a, b, c; Pandarinath et al 1999a, b; Enzel et al 1999). A relationship between sedimentation and tectonics

Keywords. Late Quaternary; lithofacies; luminescence chronology; stratigraphic correlation; fluvial response; climate change. 


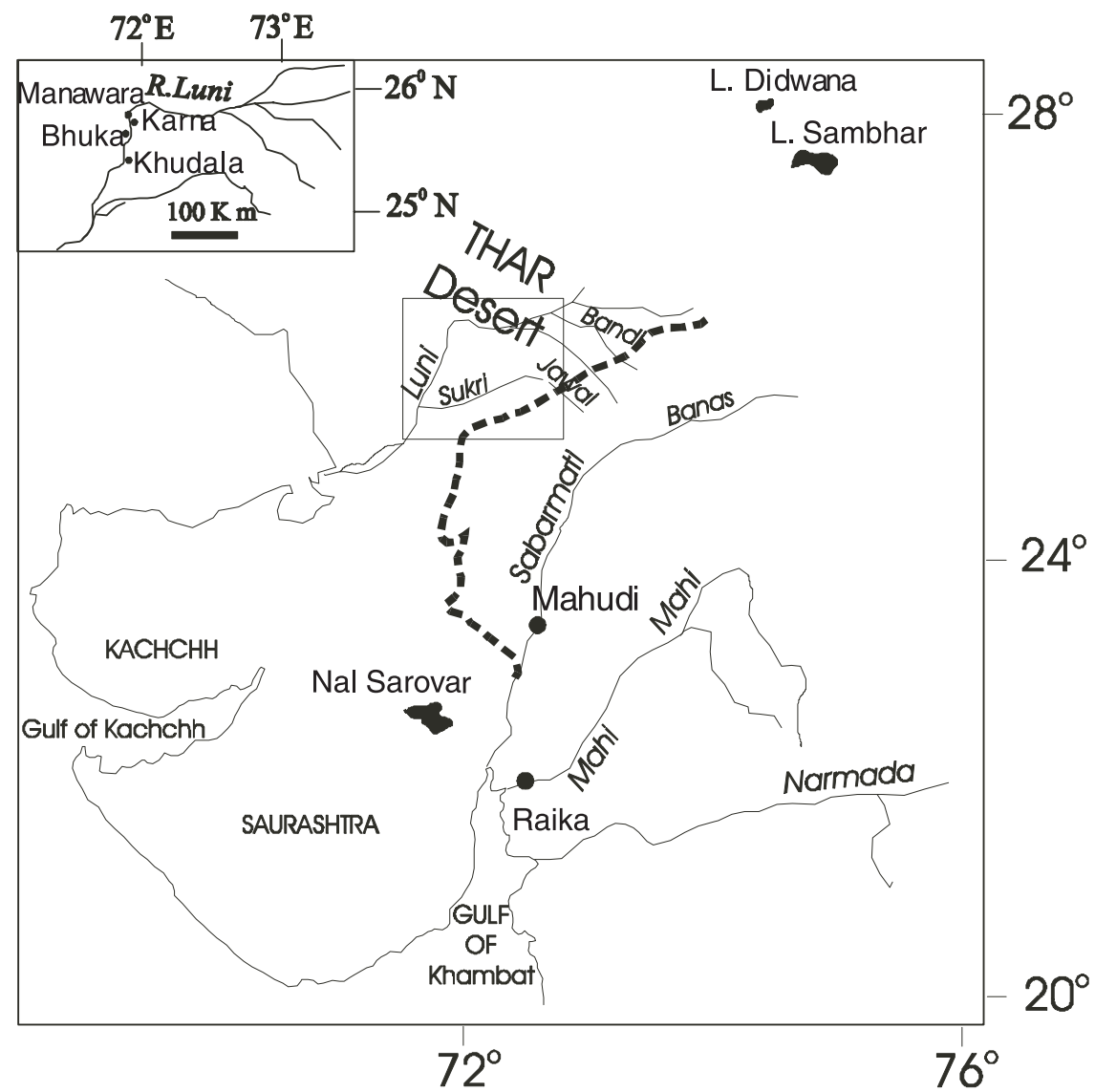

Figure 1. Location map of the studied sections in the Luni, Sabarmati and Mahi rivers. The inset shows the locations examined in detail for the lower Luni basin. Dashed line indicates the palaeo-dunefield margin taken from Goudie et al (1973).

during the late Pleistocene and Holocene has been envisaged for the Gujarat alluvial plains by several workers (Sareen et al 1993; Maurya et al 1995, 1997a, 2000; Merh and Chamyal, 1997; Jain et al 1998; Rachna et al 1999a, b; Chamyal et al 2003).

It is important to understand what are the dominant allostratigraphic forcing mechanisms in the region, a pre-requisite for which is a regional chronostratigraphic framework. Attempts at regional inter-valley correlations across different semi-arid western Indian rivers (Merh and Chamyal 1997; Tandon et al 1999) have been based dominantly on lithostratigraphic data. The recent chrono-stratigraphic studies in the lower Luni, Mahi and Sabarmati basins (Tandon et al 1997; Jain et al 1999; Juyal et al 2000; Kar et al 2000; Srivastava et al 2001; 2003b) provide an opportunity to establish a preliminary inter-valley chrono-stratigraphic framework. Here we highlight the comparative analysis of facies and stratigraphic development in some of the important exposed sections from these river valleys and then discuss the key controls.

\section{Facies and stratigraphic development}

\subsection{Luni basin, Thar desert}

The Luni river and its tributaries constitute the major drainages in the Thar desert. It shows characteristics of ephemeral desert stream (Sharma et al 1984). Jain et al (1999), on the basis of preliminary investigations, proposed an informal classification of the exposed deposits in the lower Luni river basin (figure 1, inset) into three distinct succession types, type I, II and III. Further studies suggested that the type I succession was fundamentally different from the type II and type III successions with respect to facies associations and forcing mechanisms that generated these deposits (Jain 2000; summarised below). This led to a revised classification into type I and type II (figure 2ah) successions that are separated by a large hiatus (Jain et al 2004); the revised type II succession contains the previous type II and type III successions of Jain et al (1999).

Type 1 succession is laterally extensive and occurs up to a depth of $\sim 300 \mathrm{~m}$ in the subsurface 
(drill cores, well sections, bore hole logs; Bajpai et al 2001). A detailed examination of the exposed, continuous, $\sim 14 \mathrm{~m}$ thick succession between Sindhari and Bhuka reveals multistoried gravel-sand sheets and well developed overbank heterolithic facies with incipient pedogenesis (figure 3a). There is a lack of fossil/archaeological material. Typically, there are complex multistoried gravel sheets (figure 2c). These are overlain by patchily developed, rhizocretionary, medium-to-fine sands, which are in turn overlain by pedogenically modified fine sand-mud alternations (figure $3 \mathrm{~b}$ ). Sheet scale (e.g., gravel-sand-mud successions) fining-up trend is common, and each cycle begins with gravel sheets overlying the heterolithic facies with an erosive contact (figure $2 \mathrm{~d}$ ). There is a general uniformity of palaeocurrent directions towards SSW (figure 3). The deposits of the type 1 succession are interpreted to be from gravel bedload braided streams in an extensive alluvial plain and a subsiding basin (Jain et al 2004). The stable isotopic $\left(\delta^{18} \mathrm{O}\right.$ and $\left.\delta^{13} \mathrm{C}\right)$ composition of the pedogenic calcrete in the type 1 succession suggests a relative dominance of $\mathrm{C}_{3}$ flora and summer-monsoon precipitation as compared to that in the type 2 succession (Jain and Tandon 2003b).

The preliminary thermoluminescence (TL) and optically stimulated luminescence (OSL) investigations on the type 1 succession suggested that the deposits were $>400 \mathrm{ka}$; this led to the speculation that the deposition might have occurred during the middle or early Pleistocene (Jain et al 1999). Later, detailed analysis of the type 1 succession based on sedimentological, palaeoclimatic and stable isotopic (carbon and oxygen) composition of pedogenic carbonate suggested that the previous upper age boundary of $400 \mathrm{ka}$ can be pushed further, and the deposition perhaps occurred during the period between Plio-Miocene boundary and the start of glacial-interglacial cycles typical of the Quaternary (Jain et al 2004).

Type 2 succession is patchily developed, and is inset within the type 1 succession and separated from it by a large hiatus. It is best observed in the Karna (KN), Bhuka (BH1A), Khudala (KH) and Manawara (MN2) sections (figure $2 \mathrm{e}-\mathrm{h}$ ). Type 2 succession represents distinct, laterally or vertically juxtaposed depositional environments, and contains fossil/archaeological materials (artefacts, gastropod shells, ostrich eggshells and chalcolithic and medieval pottery; Mishra et al 1999). The stable isotopic composition of calcrete shows systematic temporal variations that correspond with the vegetational/precipitation changes during the late Pleistocene (Jain and Tandon 2001). Some of the key sections are shown in figure 4 . The following facies associations and depositional environments have been identified in the type 2 succession (table 1).

1. Multistoried gravel sheets + pedogenically modified muds (gravel-bedload braided stream) (figures $2 \mathrm{~g}, 4 \mathrm{a})$.

2. Red silty fine sands (sediment gravity flows or sheet floods) (figures 2e, 4c).

3. Horizontally bedded fine to very fine sands with interbedded calcrete gravel lenses (high-energy ephemeral stream deposits) (figures $2 \mathrm{~g}, 2 \mathrm{~h}, 4 \mathrm{a}$, $4 \mathrm{~b})$.

4. Sand-silt alternations (ephemeral sand bed streams) (figures 2e, 4c).

5. Pedogenically modified silty fine sands and sandy gravel association (mixed load meandering streams).

6. Pebbly coarse sand + medium to fine sand couplets (sheet-flow deposits).

7. Well sorted massive fine to very fine sands (aeolian dunes or sand sheets) (figures 2e, f).

8. Fine silts + Fine sands (recent overbank and slackwater deposits).

Palaeocurrent directions are generally towards SSE (figures $4 b, c)$. The physical stratigraphy and the optically stimulated luminescence (OSL) ages derived from quartz in these deposits are given in table 2 . The ages were based on multiple aliquot of quartz (see Jain and Singhvi 2001; Jain et al 2003a for details).

\subsection{Sabarmati and Mahi basins, the Thar margin}

The Sabarmati and Mahi rivers in Gujarat originate from the Aravalli mountain range and flow through the extensive Gujarat alluvial plains before they finally meet the Gulf of Khambat (Merh 1995; figure 1). These rivers in their middle and lower reaches flow in close proximity to the reconstructed palaeomargin of the Thar desert (figure 1). The presence of stabilised aeolian dunes in the landscape suggests that the Thar desert margin expanded to these areas in the past. The modern precipitation varies from about 300 to $700 \mathrm{~mm}$ and the mean annual rainfall in the studied reaches is about $650 \mathrm{~mm}$. The inferences in this section are largely based on previous studies by Tandon et al (1997), Juyal et al (2000), Jain (2000), Srivastava et al (2001) and Jain and Tandon (2003a).

\subsubsection{Sabarmati basin}

Several authors have described the exposed successions with emphasis on the river Sabarmati (e.g., Foote 1898; Sankalia 1945; Zeuner 1950; 


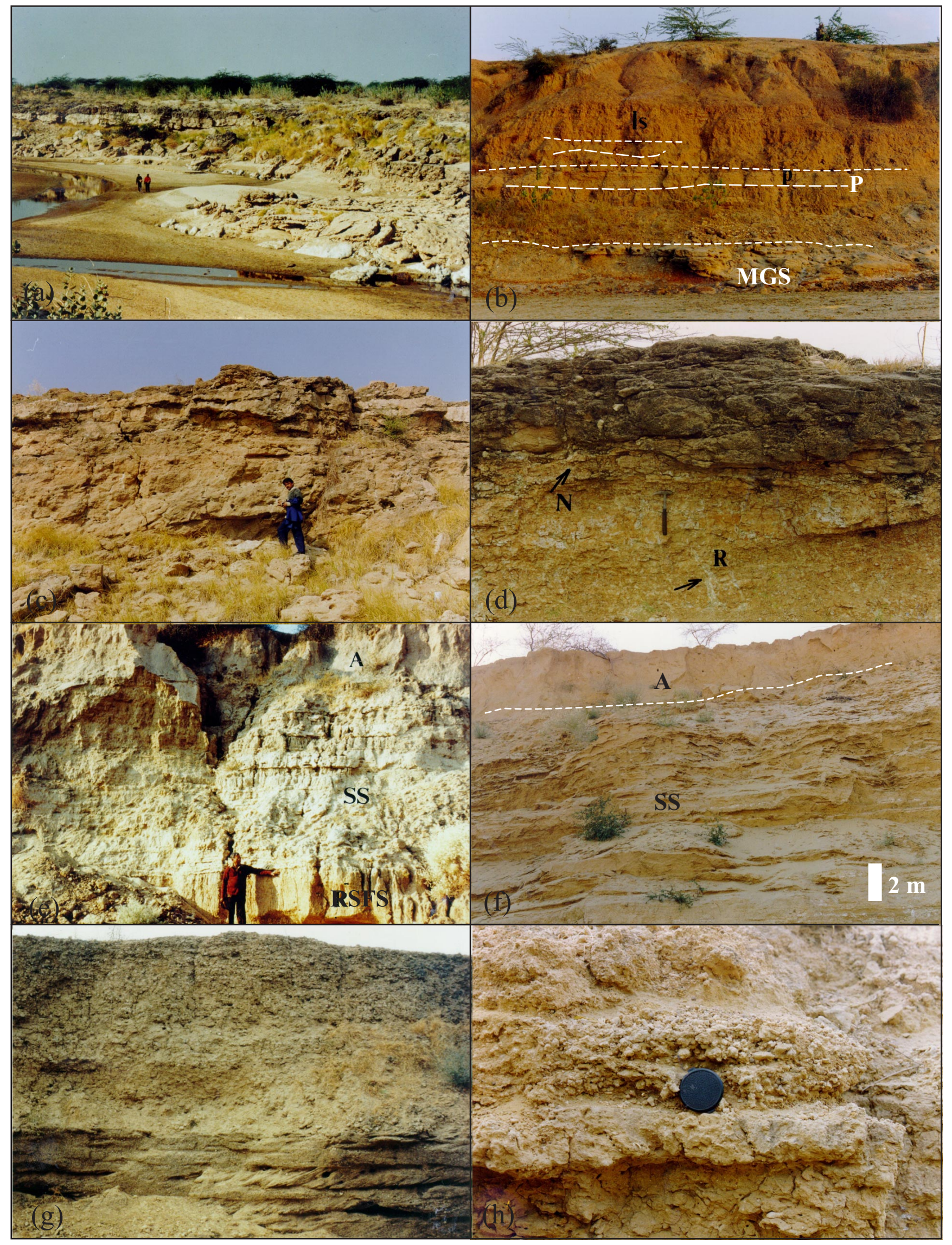

Figure 2. 
Sareen 1992; Sareen et al 1993; Sridhar and Chamyal 1996; Tandon et al 1997). Previous studies suggest that about $80 \mathrm{~m}$ thick subsurface Quaternary deposits rest unconformably on Precambrian granites near Dharoi, in the foothill zone. Further to the south, the thickness increases to $200 \mathrm{~m}$ and eventually to $300 \mathrm{~m}$ at Cambay (Chandra and Chaudhary 1969).

Geological mapping of the exposed successions of the Sabarmati plains resulted in a four-fold stratigraphic subdivision (Sareen, 1992; Tandon et al 1997). The basal Waghpur Formation consists of conglomerate and pale red sand association. The pale red sand is affected to varying degrees by calcareous pedogenesis. The succeeding Mahesana Formation is divided into a lower heterolithic member and an upper sand member. There is an occurrence of pronounced reddened horizon, which has been used for regional correlations from the Thar to the Gujarat alluvial plains (Tandon et al 1999). Overlying these predominantly alluvial units is the Akhaj Formation, which consists of well-sorted, fine, buff sand. The youngest unit - the Sabarmati Formation - comprises unconsolidated alluvium, derived from the Aravalli highlands, transported by the modern Sabarmati channel.

Detailed investigations of one of the most well preserved sections, near Mahudi has been made by Jain (2000) and Srivastava et al (2001) and Jain and Tandon (2003a). The latter authors divided the entire succession into six units representing different environments:

- gravel bedload braided (figures 5a-e);

- seasonal wetland (figure 5f);

- meandering (figure $5 \mathrm{~g}, \mathrm{~h}$ ); and

- aeolian (figure 5i).

They further investigated the potential of using clay minerals in the mud dominated units as a palaeoclimatic indicator. A summary based on these studies is presented in table 3 .

Limited efforts at dating the gravel deposits that are generally exposed at the base of these river sections (Waghpur formation and its equivalents) (figure $5 \mathrm{a}-\mathrm{d}$ ) remain inconclusive. The deposits were found to be older than about $300 \mathrm{ka}$ (Tandon et al 1997) implying that quartz extracted from these deposits was in the saturation limit, and hence beyond the luminescence dating range. An indirect minimum age for these gravel deposits (>190 ka) was derived from the extrapolation of the age of the lower middle Palaeolithic implements, which underlie the miliolite deposits dated to 69-196 ka (Baskaran 1985; see Merh and Chamyal 1997 for details). However, later studies indicate that lithostratigraphic correlation between the basal clays in the Sabarmati, Mahi and Narmada, and the coastal miliolites of Saurashtra (e.g., Chamyal and Merh 1992; Merh and Chamyal 1997) is uncertain. For example, the basal clay unit in the Raika section, Mahi basin has been shown to be of marine origin (Rachna et al 1998) and is related to OIS 5e marine highstand (Juyal et al 2000), while it has been argued by Jain and Tandon (2003a) that the basal muds in the Mahudi are floodplain deposits of gravel bedload braided streams (figure 5a, c, e), perhaps of pre-Quaternary age. Jain and Tandon (2003a) argue that the late Pleistocene gravels in the region have a smaller thickness, and contain reworked calcrete as an important clast constituent, as compared to the basal gravels, which are several meters thick and contain abundant ferruginous nodules, thus suggesting a more humid climate in the past (Jain and Tandon 2003a). It is unlikely that ferruginous nodule formation occurred during the Quaternary due to the predominance of carbonate nodules in the deposits of this period. Further, in the Mahudi section, these older gravels show a significant hiatus with the late Pleistocene deposits represented by extensive calcretisation (figure $5 \mathrm{c}, \mathrm{d}$ ).

The upper parts of these sections (Mehasana formation) are tied more robustly through the regional red horizon (figure 5i) developed in the overbank deposits of meandering rivers. This has not only been observed in the Mahi, Sabarmati and Luni valleys (Tandon et al 1999) but also in the sediment core in the Nal region (Prasad et al 1998; Pandarinath et al 1999a). It was suggested that this unit was a land-surface for some length of time (Zeuner 1950) and was deposited during OIS 5e (Pant and Chamyal 1990). Later work suggested that deposition occurred between about 58 and $39 \mathrm{ka}$ (OIS 3) on the basis of thermoluminescence (TL) dating (Tandon et al 1997). Recently,

\section{Figure 2 caption}

Figure 2. (a) Overall view of the exposed type 1 succession near Sindhari consisting of an alternation of multistoried gravel sheets (MGS) and heterolithic facies (HF); (b) MGS and sandstone deposits overlain by the overbank deposits with interbedded palaeosols (P); (c) Up to three meters thick MGS, (d) MGS overlying the HF with an erosive contact. HF shows colour mottles, pedogenic calcrete nodules (N) and rhizocretions (R). Type 2 succession : (e) Khudala section showing red silty fine sand (RSFS) overlain by sand-silt alternations (SS) and capped by an aeolian accumulation (A); (f) Sand-silt alternations in Khudala section showing lateral splitting and amalgamation of silt beds around sand lenses; (g) Lower MGS (gravel bedload braided streams) overlain by horizontally bedded fine sands (high energy ephemeral streams) in the Karna section; (h) Calcrete gravel lenses associated with the horizontally bedded fine sands. 


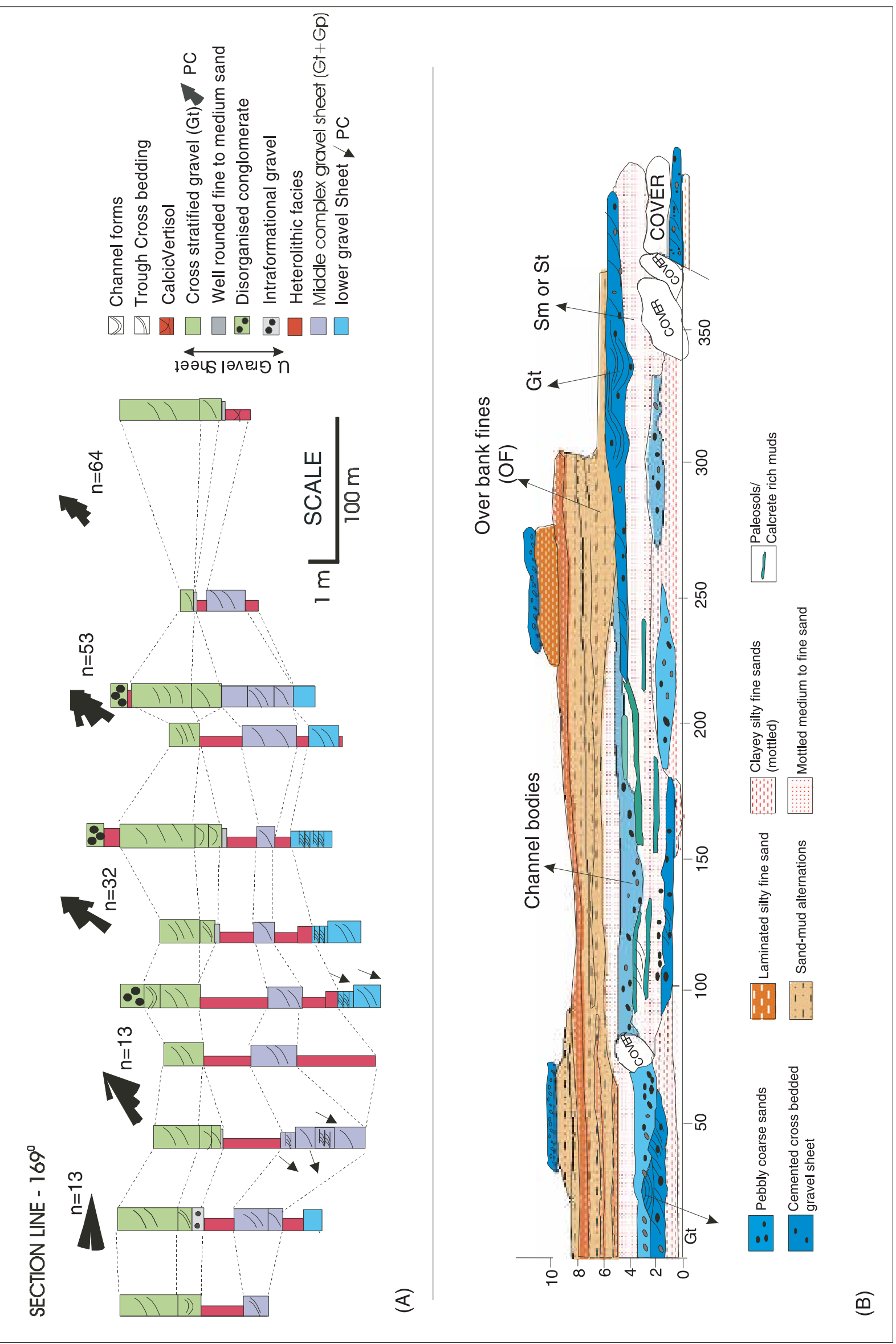


Srivastava et al (2001) provided OSL ages of 54$30 \mathrm{ka}$ from the Mehasana formation. Both TL and OSL data are generally in agreement with the data from the Nal Sarovar core, in which the red sand-silts have been dated to $\sim 50$ ka by infra-red stimulatedluminescence (Prasad et al 1998). Pandarinath et al (1999a) suggested that the formation of the red horizon occurred during a period of high rainfall period punctuated by a dry season on the basis of illite crystallinity and the presence of gypsum and calcareous nodules.

The subsequent aggradation occurred by aeolian mechanisms, which resulted in the stabilised dunes of the Akhaj formation. These aeolian deposits have been variously dated to $\sim 22 \mathrm{ka}$ (Wasson et al 1983), $12 \mathrm{ka}$ (Srivastava et al 2001) and $5 \mathrm{ka}$ (Tandon et al 1997), suggesting different pulses of aeolian activity in the region. There was also a period of meandering stream deposits reckoned to be $\sim 14-12 \mathrm{ka}$ (Jain and Tandon 2003a) and the subsequent incision by the present river was bracketed to between 12 and $4.5 \mathrm{ka}$ (Srivastava et al 2001).

\subsubsection{Mahi basin}

The detailed Quaternary lithostratigraphy of the exposed alluvial successions in the Mahi river basin has been given in Merh and Chamyal (1997). Some important aspects from the Raika section are described here. The basal unit consists of a meter scale, dark brown (10 YR 4/2), nonstratified sandy mud facies. The presence of planktonic and benthic foraminifera indicate a marine origin (Rachna et al 1998) that has been linked to the OIS 5e highstand (Juyal et al 2000). The bottom muds are overlain by fluvial gravel (Raika formation of Merh and Chamyal 1997) and further by inter-bedded alluvial/limnic mud and marl (M1, M2 and M3 of Jain et al 1998). The muds are overlain by a channelised fluvial gravel-sand complex (Poicha member; Merh and Chamyal 1997). The upper part comparable with the Mehsana formation of the Sabarmati consists of alluvial silts containing distinct pedogenically modified horizons (Chamyal and Merh 1995; Arathi 1996; Khadkikar et al 1996). Lithofacies development in the upper parts of the sections of the Mahi basin is broadly similar with those in the Sabarmati basin, and the reddened silt horizon has been used for intervalley correlation (Pant and Chamyal 1990; Tandon et al 1999). The youngest deposits (figure 4) in the basin are aeolian silts and silty sands. Similar aeolian deposits have been classified as Phajalpur Member and the dunal sands of the Timba Member as Singrot formation (Merh and Chamyal 1997).

Some estimates of the chronology of the successions are given in Merh and Chamyal (1997). These were based on global climatic changes and sea-level curve correlations. They suggested that the reddening (sub-aerial weathering) of the silt cannot be older than $140 \mathrm{ka}$. Jain et al (1998) suggested, on the basis of comparison with the TL chronology of the Sabarmati succession (Tandon et al 1997), that the G2 gravel at Raika is likely to be about $60 \mathrm{ka}$ or older. The first definite ages on the Raika section were provided by Juyal et al(2000) who estimated the age of the red member between 40 and $25 \mathrm{ka}$ on the basis of an OSL (optically stimulated luminescence) chronology. These authors identified two phases of aggradation: 52 to $44 \mathrm{ka}$ and 37 to $30 \mathrm{ka}$ (Juyal et al 2000).

The lower gravel and mud-marl units in the Raika section record a neotectonic event during the late Pleistocene (Maurya et al 1997a; Jain et al 1998). A linkage between gulleys, overall drainage pattern and the tectonic lineaments has been suggested (Rachna et al 1999a, b; Chamyal et al 2003). Mid-Holocene marine transgression (Hashmi et al $1995)$ is indicated in the fluvio-marine intercalations of valley fill terraces described by Maurya et al (1997b) from the lower Mahi valley.

\section{Discussion}

In this section the stratigraphic correlation for the three basins, and the fluvial response to the dominant forcing mechanisms are discussed.

\section{Figure 3 caption}

Figure 3. Details of the type 1 succession in the lower Luni basin: (a) Detailed facies documentation, their lateral continuity and palaeocurrent directions of the gravel and sandstone bodies from the exposed gully section near Sindhari shown in figure 2(a). The sequence shows three gravel-sand sheets with two intervening heterolithic facies horizons. Gravel-sand sheets show multistoried character. Palaeocurrent directions for the topmost gravel sheets were measured in $200 \times 200 \mathrm{~m}$ grids and are dominantly southwesterly. Heterolithic facies (overbank) and gravel facies (channel) show lateral pinching out and thickening; (b) Lateral lithofacies diagram of the type 1 succession near Bhuka. Lower part of the section shows an interfingering of channel and overbank facies. The upper part of the section is dominated by overbank facies. Top of the section is overlain by a gravel sheet, which is patchily preserved. The overbank deposits are pedogenically modified with occasionally the presence of thick calcisols. A fining up trend from gravel to fine sands to muds (occasionally calcrete rich) is common. 


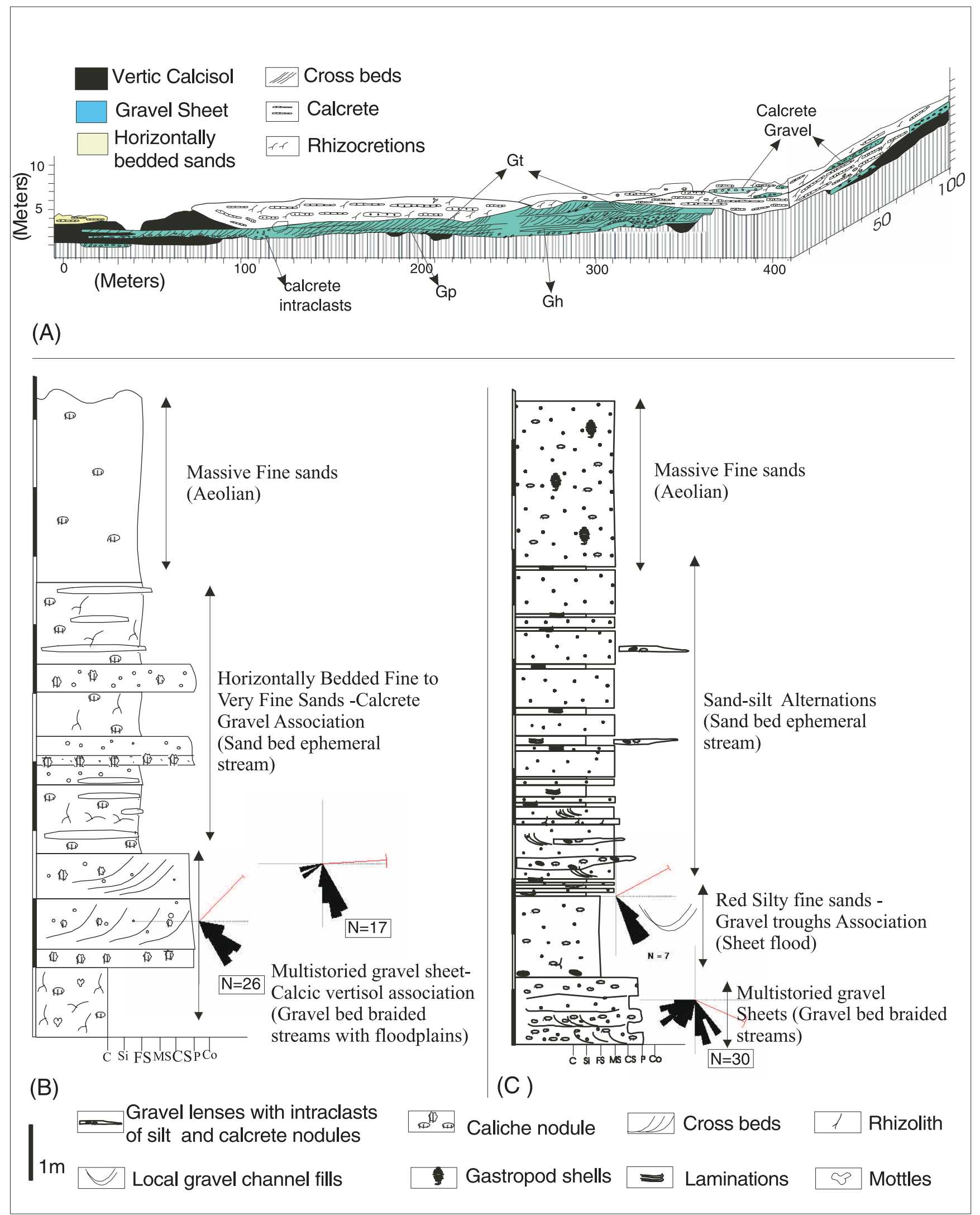

Figure 4. 


\subsection{Stratigraphic correlation}

Correlation in continental sedimentary facies that are generally unfossiliferous to poorly fossiliferous is a common problem. In the studied sections from the three basins, there is a general vertical trend in facies development from coarse clastics to fine grained alluvial facies and finally to fluvio-aeolian and aeolian facies. A regionally persistent unit in both the Mahi and Sabarmati basins is the reddened sand/silt unit. Jain and Tandon (2003a) pointed out that reddening occurred due to concomitant pedogenic alteration in the overbank deposits of meandering rivers during OIS 3, and hence the red horizon can broadly be used as a marker for lithostratigraphic correlation for this period. Interestingly, in the Luni basin, evidence of reddened silty fine sands is found in the Khudala section and the pedogenic modification appears to have been concomitant with that in the Gujarat alluvial plains (RSFS in figure 1e; Tandon et al 1999; Kar et al 2000).

Although, the pedogenic horizon can potentially be used for stratigraphic correlation, one of the key questions in tying up the late Quaternary sections is whether lithofacies associations in the individual sections can be used as a basis of stratigraphic correlation. This question has been examined by putting together the known age deposits in these basins in a spatio-temporal perspective. Using the luminescence chronology and physical stratigraphy developed for individual basins (Tandon et al 1997; Juyal et al 2000; Kar et al 2000; Srivastava et al 2001; Jain et al 2004; Jain and Tandon, 2003a), a lithological comparison can be attempted for the Luni, Mahi and Sabarmati basins.

Figure 6 shows the dominant lithologies, depositional environments and the time of deposition for different units in the three basins. It is clear that the gravel deposits occurred during OIS 1 and OIS 5 in the Luni basin (Jain et al 2004) and possibly during OIS 4 in the Mahi basin (Juyal et al 2000). The fine-grained deposits of meandering streams are found dominantly during OIS 3 in the Mahi and Sabarmati, whereas in the Luni, the only instance of such a deposit occurred during OIS 1. On the other hand, sand deposits related to ephemeral stream and sheet flow/flood are ubiquitous from OIS 4 to OIS 1 but only in the Luni basin. The OIS 5e and OIS 1 fluvio-estuarine terraces (4-2 ka) occur in the Mahi valley (Rachna et al 1998; Maurya et al 1997b). Figure 6 suggests that cross-valley lithostratigraphic correlation is inappropriate as the deposits of mud, sand and gravel are present during various periods in the three river basins. Thus, our earlier conjecture (Tandon et al 1999) of using gravel beds as markers for OIS 5, and in general the lithostratigraphic correlations for the western Indian alluvial deposits from the Thar to Gujarat (Merh and Chamyal 1997 and references therein), do not hold in the light of new data. The inability to correlate on the basis of lithology is not surprising considering that the climate/tectonics/sea level related process-response linkages are likely to have been different in these basins. In the following sections we examine these processes in greater detail.

Most of the studied sections in the three river basins are far from the influence of sea, presently, and it is unlikely that during much of the record that these successions represent (late OIS 1 to OIS 4 ), would sea level have any significant role (Blum and Törnqvist 2000). Although marine deposits have been documented in the lower Mahi river valley for OIS 1 and OIS 5e (Rachna et al 1998; Maurya et al 1997b), there is no clear documentation of large-scale incision or valley fills in response to sea level changes during the late Pleistocene. The latest incision resulting in the present day river valley in fact occurred during the onset of the Holocene in the Mahi and Sabarmati rivers further strengthening the fact that the fluvial response in these reaches was not governed by the eustatic changes. In the Thar desert, it is considered very unlikely that there is any significant linkage between sea level change and the behaviour of river Luni as the river looses much of its discharge downstream. During the last glacial cycle the river would have

\section{Figure 4 caption}

\footnotetext{
Figure 4. Details of the type 2 successions in the lower Luni basin (a) Lateral diagram of the exposed section near Karna. There is a prominent multistoried gravel sheet - Vertic calcisol association at the base corresponding to OIS 5 a (Jain et al 2004). This is overlain by calcretised horizontally bedded sand sheets with some intercalated calcrete gravel lenses. The sands were deposited by high energy ephemeral sand bed streams during Late OIS 3 and OIS 2; (b) the stratigraphic succession and the facies details from the Karna section. Lower gravel-paleosol association is overlain by horizontally-bedded fluvial sands containing some remnant aeolian sand pockets. The alluvial deposits are covered by aeolian deposits of recent age. The palaeocurrent directions in the lower gravel are SE to SSE. (c) the stratigraphic succession and the facies details from the Khudala section (see figure 2f). The red horizon is correlatable with the OIS 3 red horizon of Gujarat alluvial plains (see figure $5 \mathrm{~g}$ ) and is overlain by sand-mud alternations (deposits of ephemeral sand bed streams) corresponding to OIS 1 $(10-12 \mathrm{ka})$. There were two pulses of aeolian activity around $10 \mathrm{ka}$ and $3 \mathrm{ka}$ (Kar et al 2000). This hiatus is reflected by the development of the stage-1 calcrete profile in the older aeolian deposits. There are bi-modal palaeocurrent directions in the lower gravel towards SSE and SW, and the sand-gravel filled troughs in the overlying red sands show a SE palaeocurrent direction.
} 
Table 1. Details of the lithofacies assemblages and environmental interpretations from the type 2 succession, lower Luni basin.

\begin{tabular}{|c|c|c|c|}
\hline Facies association & Description & Location & $\begin{array}{l}\text { Environmental } \\
\text { interpretation }\end{array}$ \\
\hline $\begin{array}{l}\text { Multistoried gravel } \\
\text { sheets (MGS)- } \\
\text { pedogenically mod- } \\
\text { ified muds }\end{array}$ & $\begin{array}{l}\text { Up to } 5 \mathrm{~m} \text { thick; generally present at the base of } \\
\text { the cliff sections or on topographically high sur- } \\
\text { faces above the Luni gorge. }\end{array}$ & $\begin{array}{l}\text { Karna, Bhuka, } \\
\text { Khudala, Man- } \\
\text { awara, Lohida }\end{array}$ & $\begin{array}{l}\text { Gravel-bedload } \\
\text { braided stream }\end{array}$ \\
\hline $\begin{array}{l}\text { Red silty fine sands } \\
\text { (RSFS) }\end{array}$ & $\begin{array}{l}\text { Massive, ill sorted, } 2.5 \text { to } 3 \mathrm{~m} \text { thick individ- } \\
\text { ual beds, reddish chroma, moderately cemented, } \\
\text { incipient calcrete nodule development. }\end{array}$ & Khudala & $\begin{array}{l}\text { Sediment grav- } \\
\text { ity flows or } \\
\text { sheet floods }\end{array}$ \\
\hline $\begin{array}{lr}\text { Horizontally } & \text { bed- } \\
\text { ded fine to } & \text { very } \\
\text { fine sands } & \text { with } \\
\text { interbedded } & \text { cal- }\end{array}$ & $\begin{array}{l}\text { Moderate to well sorted (with disseminated coarse } \\
\text { sand grains and pebbles); few centimetres thick } \\
\text { beds; millimetre-scale parallel laminations and } \\
\text { primary current lineation; associated calcrete }\end{array}$ & Karna & $\begin{array}{l}\text { High-energy } \\
\text { ephemeral } \\
\text { stream deposits }\end{array}$ \\
\hline
\end{tabular}
crete gravel lenses gravel lenses.

$(\mathrm{HBFS}+\mathrm{CG})$

Sand-silt alternations (SSA)
Well-sorted fine to very fine sands and laminated silts; silt thickness: 5-20 cm; sands : variable thickness and may show indistinct cross stratification or horizontal laminations defined by micas.
Pedogenically modified silty fine sands and sandy gravel association (SFS + SG)

\section{Pebbly coarse sand} + medium to fine sand couplets $(\mathrm{PCS}+\mathrm{MFS})$

\begin{abstract}
Dominantly silty fine sands with minor thin gravel intercalations that pinch out laterally in less than $10 \mathrm{~m}$; pedogenic modification and stage- 2 calcrete profile development.
\end{abstract}

Khudala

Ephemeral sand bed streams

$\begin{array}{ll}\text { Near Bhuka } & \text { Mixed } \\ & \text { load meander- } \\ & \text { ing streams }\end{array}$

\begin{tabular}{|c|c|c|}
\hline $\begin{array}{l}\text { Pebbly coarse sands: thin }(\sim 30 \mathrm{~cm}) \text { massive, } \\
\text { matrix-supported sheets. Medium to fine sands } \\
\text { of comparable thickness overlie the pebbly sands } \\
\text { with a gradational contact, and may be over- } \\
\text { lain by a thin silt bed. Several fining up cycles } \\
\text { observed. }\end{array}$ & Near Manawara & Thin sheet-flows \\
\hline $\begin{array}{l}\text { Fine sand to coarse silt range comprising about } \\
95 \% \text { of the total load. In places, the sands show } \\
\text { reddish chroma and stage- } 1 \text { calcrete profile devel- } \\
\text { opment. Dunal morphology may be present. }\end{array}$ & $\begin{array}{l}\text { Karna, Bhuka, } \\
\text { Khudala }\end{array}$ & $\begin{array}{l}\text { Aeolian dunes } \\
\text { or sand sheets }\end{array}$ \\
\hline Alternating beds of silt and medium to fine sand. & $\begin{array}{l}\text { Bhuka, Karna, } \\
\text { Khudala }\end{array}$ & $\begin{array}{l}\text { Recent flood- } \\
\text { plains and slack- } \\
\text { water deposits }\end{array}$ \\
\hline
\end{tabular}

Well sorted massive fine to very fine sands (MFS)

Fine sand to coarse silt range comprising about $95 \%$ of the total load. In places, the sands show

Karna, Bhuka, Khudala water deposits been even drier and the studied reaches even more inland.

On the tectonic front, there are evidences of large scale lineaments in both the Thar desert (Bajpai et al 2001) and Gujarat (Maurya et al 1995; Rachna et al 1999a, b). Various evidences of the presence of neotectonism are summarised by Chamyal et al (2003). These are:

- 300-800 m thick subsurface sediments, and folding and faulting of Tertiary rocks in Saurashtra and W. Kachchh.

- The late Pleistocene and Holocene deposits contain gorge like valleys, $30-50 \mathrm{~m}$ high cliffs, ravines and entrenched meanders. A relationship between tectonic lineaments and present drainage patterns has been pointed out by various authors (e.g., Sareen et al 1993; Maurya et al 2000; Rachna et al 1999a, b).

Absolute chronology for tectonic activity in the older deposits of Tertiary age is lacking; it can only be argued that the activity occurred prior to late Pleistocene. Similarly, although the drainage patterns are confined to tectonic lineaments, deep ravines and valleys are expressions of incisions that can be driven also by climate (Retallack 1986; Blum and Törnqvist 2000; Gibling et al 2004; discussed later). A more direct evidence of tectonics in the stratigraphic record is in the form of late Pleistocene and Holocene penecontemporaneous deformations (Maurya et al 1997a, Sohoni and Malik 1998; Jain et al 1998). The locally developed soft sediment deformation features can represent 
Table 2. Spatio-temporal context of the type 2 succession in the Thar desert from Jain (2000) and Jain et al (2004). The horizontal axis refers to different regions in the lower Luni basin (locations shown in the inset of figure 1). The stages of calcrete development after Machette (1985).

\begin{tabular}{|c|c|c|c|c|}
\hline \multicolumn{5}{|c|}{ Fluvial pattern } \\
\hline OIS & Khudala* & Bhuka & Manawara & Karna \\
\hline 1 & $\begin{array}{l}\text { Aeolian }(\sim 3 \mathrm{ka}) \\
\text { Aeolian } \\
(12-8 \mathrm{ka}) \\
\text { Ephemeral sand } \\
\text { bed streams } \\
(12-8 \mathrm{ka})\end{array}$ & $\begin{array}{l}\text { Large floods }- \text { SWD }(<1 \mathrm{ka})^{* *} \\
\text { Aeolian }(\sim 3 \mathrm{ka}) \\
\text { Meandering }- \text { Stage } 2 \\
\text { Calcrete }(\sim 12 \mathrm{ka}) \\
\text { Gravel bed braided } \\
(\sim 14 \mathrm{ka}) \\
\text { Incision }(\sim 14 \mathrm{ka})\end{array}$ & $\begin{array}{l}\text { Incision }(\mathbf{1}-\mathbf{3} \mathbf{k a}) \\
\text { Aeolian }(\sim 3 \mathrm{ka}) \\
\text { Sheet flows }(9-5 \mathrm{ka}) \\
\text { Incision }(\sim 14 \mathrm{ka}) \\
\text { Gravel braided } \\
(\sim 11 \mathrm{ka})\end{array}$ & $\begin{array}{l}\text { Aeolian (recent) } \\
\text { Floodplains } \\
(0 \text { to }<250 \mathrm{a})\end{array}$ \\
\hline 2 & & & & \\
\hline 3 & $\begin{array}{l}\quad- \\
\text { Pedogenesis/ } \\
\text { Regional } \\
\text { reddening } \\
(70-30 \mathrm{ka})\end{array}$ & - & $\begin{array}{l}\text { Aeolian - Stage } 2 \\
\text { calcrete }(27 \pm 6 \mathrm{ka})\end{array}$ & $\begin{array}{l}\text { Ephemeral sand bed } \\
\text { streams; Stage } 3 \\
\text { calcrete }(300-20 \mathrm{ka})\end{array}$ \\
\hline$\frac{4}{5 a-d}$ & $\begin{array}{l}\text { Sheet flood } \\
(52-86 \mathrm{ka})\end{array}$ & $\begin{array}{l}\text { Braided (gravel) with } \\
\text { floodplains - Calcic } \\
\text { Vertisol }\end{array}$ & - & $\begin{array}{l}\text { Braided (gravel) with } \\
\text { floodplain } \\
(\sim 80 \mathrm{ka})\end{array}$ \\
\hline $5 \mathrm{e}$ & $\begin{array}{l}\text { Braided (gravel) } \\
\text { without flood- } \\
\text { plains > } 90 \mathrm{ka}\end{array}$ & - & - & - \\
\hline
\end{tabular}

${ }^{*}$ Chronology from Kar et al (2000).

** Chronology from Kale et al (2000).

SWD - Slack Water Deposits.

major earthquakes in the past, the more recent manifestations of which can be 1819, 1956 and 2001 earthquakes in Kachchh, and the 1870 earthquake in the lower Narmada valley. Such deformation, perhaps, suggest proximity to a major fault, although, it must be noted that large earthquakes can cause soft sediment deformation features hundreds of kilometres from the epicentre.

Thus, although, there is a geomorphic expression of the underlying tectonic structure, and evidence of occurrence of earthquakes in the late Quaternary, it is difficult to evaluate the importance of tectonic movements in generating sedimentation patterns, alluvial architecture and phases of aggradation and incision. The identification of tectonic influence on sedimentation requires careful mapping and documentation of discontinuities and the alluvial architecture. (Plint et al 1993; DeCelles et al 1998), while, at present the evidence forwarded in favour of tectonic control is largely geomorphological. With the present evidence, it can at best be concluded that tectonics resulted in small-scale deformation of alluvial strata. At a larger scale, tectonic movements perhaps provided a preservation mechanism by subsidence within the graben fills (Maurya et al 1995) in the Gujarat alluvial plains. In the Thar desert, it is suggested that tectonic subsidence was insignificant during the
Quaternary resulting in a low preservation space, and therefore there was small residence time for the Quaternary alluvial sediments (Jain et al 2004). Thus, it appears that neotectonic movements have only been significant in determining the preservation space, or the lack of it, while its role in generating actual sedimentary facies, their associations, and the overall alluvial architecture remains ambiguous (Jain 2000).

In contrast to the tectonic and sea level changes, the development of alluvial facies and allostratigraphy can be interpreted, relatively directly, in terms of monsoonal changes as follows:

\subsection{Fluvial response to climate change}

\subsubsection{Luni basin}

One way of examining the control of climate on stratigraphic development is to look at the changes in depositional environment in the framework of independently known palaeoclimatic records. We have here used the precipitation curve based on the calculation of Prell and Kutzbach (1987) that has been tested against various climatic proxies from the region (Jain and Tandon 2003b).

In the lower Luni river basin, gravel bedload braided rivers are present only during the wet 


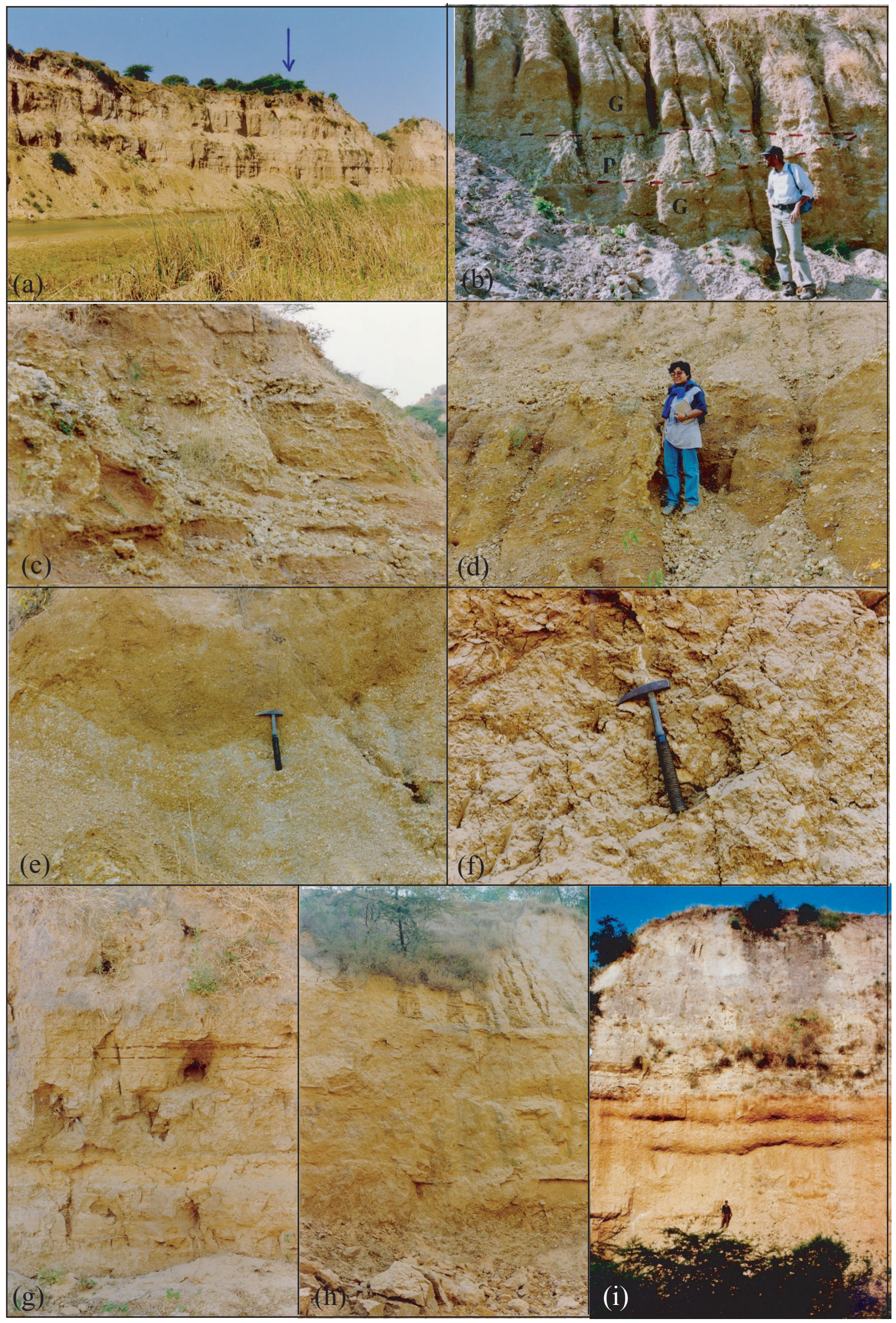

Figure 5. 
Table 3. Stratigraphic framework of the Mahudi section. Different units, their characteristic facies, and depositional environments are summarised. Ages are from earlier work in the Sabarmati and Mahi basins (see the text for details).

\begin{tabular}{|c|c|c|c|c|}
\hline Unit & Facies & Environment & $\begin{array}{l}\text { Smectite/Illite } \\
\text { ratio }\end{array}$ & Age \\
\hline Unit 6 & $\begin{array}{l}\text { Well sorted fine to very } \\
\text { fine sands }\end{array}$ & Aeolian & - & $\sim 12 \mathrm{ka} ;$ OIS- 1 \\
\hline Unit 5 & $\begin{array}{l}\text { Calcrete gravel; silty } \\
\text { fine to very fine sands; } \\
\text { fining-up succession }\end{array}$ & $\begin{array}{l}\text { Mixed load meandering } \\
\text { streams with floodplain } \\
\text { development and inter- } \\
\text { mittent pedogenesis }\end{array}$ & 4.5 & $\sim 12-14 \mathrm{ka}^{*} ;$ OIS-1 \\
\hline Unit 4 & $\begin{array}{l}\text { Calcretised fine to very } \\
\text { fine sands }\end{array}$ & $\begin{array}{l}\text { Aeolian followed by a } \\
\text { phase of pedogenesis } \\
\text { (calcrete development) }\end{array}$ & $3.4,4.3$ & $\begin{array}{l}\sim 14-30 \mathrm{ka}^{*} . \\
\text { Pedogenesis during } \\
\text { the wet phase per- } \\
\text { haps } \sim 14 \mathrm{ka} \text {; OIS- } 2\end{array}$ \\
\hline Unit 3 & $\begin{array}{l}\text { Sandy silts; silty very } \\
\text { fine sands; laminated } \\
\text { sand-silts }\end{array}$ & $\begin{array}{l}\text { Mixed load meandering } \\
\text { streams with floodplain } \\
\text { development and inter- } \\
\text { mittent pedogenesis }\end{array}$ & $\begin{array}{l}3 \text { (red horizon), } \\
2.2,1.6,2.0,1.8\end{array}$ & 60-30 ka ; OIS-3 \\
\hline Unit 2 & $\begin{array}{l}\text { Brown calcic vertisol - } \\
\text { gravel association }\end{array}$ & Seasonal wetland? & 5.5 & $\sim 125 \mathrm{ka}^{*} ;$ OIS-5e \\
\hline Unit 1 & $\begin{array}{l}\text { Gravel-vertic soil asso- } \\
\text { ciation. } \\
\text { ferruginous noundant } \\
\text { significant relief and } \\
\text { post depositional } \\
\text { weathering. }\end{array}$ & $\begin{array}{l}\text { Fluvial (gravel-sand } \\
\text { bedload streams) }\end{array}$ & - & $>300$ ka Pliocene (?) \\
\hline
\end{tabular}

The asterix $\left({ }^{*}\right)$ indicates indirect ages based on regional correlations or bracketing from the adjacent deposits (Jain and Tandon 2003a). Smectite/chlorite ratios are based on X-ray diffraction analysis of the $<2 \mu$ m size fraction from the muds (Jain and Tandon 2003a).

phases in OIS $1(\sim 14$ and $\sim 11 \mathrm{ka})$ and OIS 5. Relatively drier phases such as in OIS 3 and OIS 1 gave rise to ephemeral sand bed rivers, sheet floods and sheet flows with high aggradation rates (table 2 , figure 7 ). During the extreme arid phases such as the Last Glacial Maxima (LGM), and during relatively less arid phases such as at $3 \mathrm{ka}$ and during the early OIS 1 (11-14 ka), the streams became much less active. Aeolian deposits are present in the latter two cases, while it appears that both the aeolian and fluvial processes were inactive during the LGM (table 2, figure 7). High-frequency climatic changes between 10 and 14 ka resulted in a spectrum of environments: aeolian, gravel bedload braided, sand bed ephemeral and meandering (table 2). Three phases of incision have been identified only during the relatively wet phases in the OIS 1 deposits: $\sim 14 \mathrm{ka}, \sim 10 \mathrm{ka}$ and post $3 \mathrm{ka}$ arid phase (figure 5).

In general, there was high sediment supply in the Luni basin, giving rise to sand dominated systems. Only during the wet OIS 5 and OIS 1 did streams

\section{Figure 5 caption}

Figure 5. (a) An overall view of the exposed section near Mahudi. (b) Thick multistoried gravel sheets and the interfingering palaeosols exposed at the base of the Mahudi section. (c) Extensive and irregular development of calcrete in the lower gravel sheet suggesting that it acted as a land surface for a significant period of time. $(\mathbf{d}) \sim 1 \mathrm{~m}$ thick calcrete rich horizon capping the lower gravel. In the gravel, there are ferruginous nodules and an absence of transported calcrete suggesting a humid climate during its deposition (Jain and Tandon 2003a). This together with the fact that there is a large hiatus manifested in later extensive calcretisation points out the antiquity of these gravel deposits. (e) Isolated channel fills in the lower gravel deposits. (f) Development of slickensides and other vertic features in the mud rich deposits overlying the lower gravels. These mud deposits are in conformable relationship with the overlying alluvial deposits and have therefore been speculated to be of OIS 5 age with correlation from the Mahi basin. The clay mineral evidence from these deposits suggests a humid phase comparable with that during OIS 1 (table 3; Jain and Tandon 2003a). (g) Laminated sand-silt, and sandy silts representing overbank deposits of the mixed load meandering streams (Mehsana formation). (h) Pedogenic modification in the silty fine sands indicated by darker reddish chroma. (i) Prominent red horizon development near Vijapur overlain by buff coloured sands. 


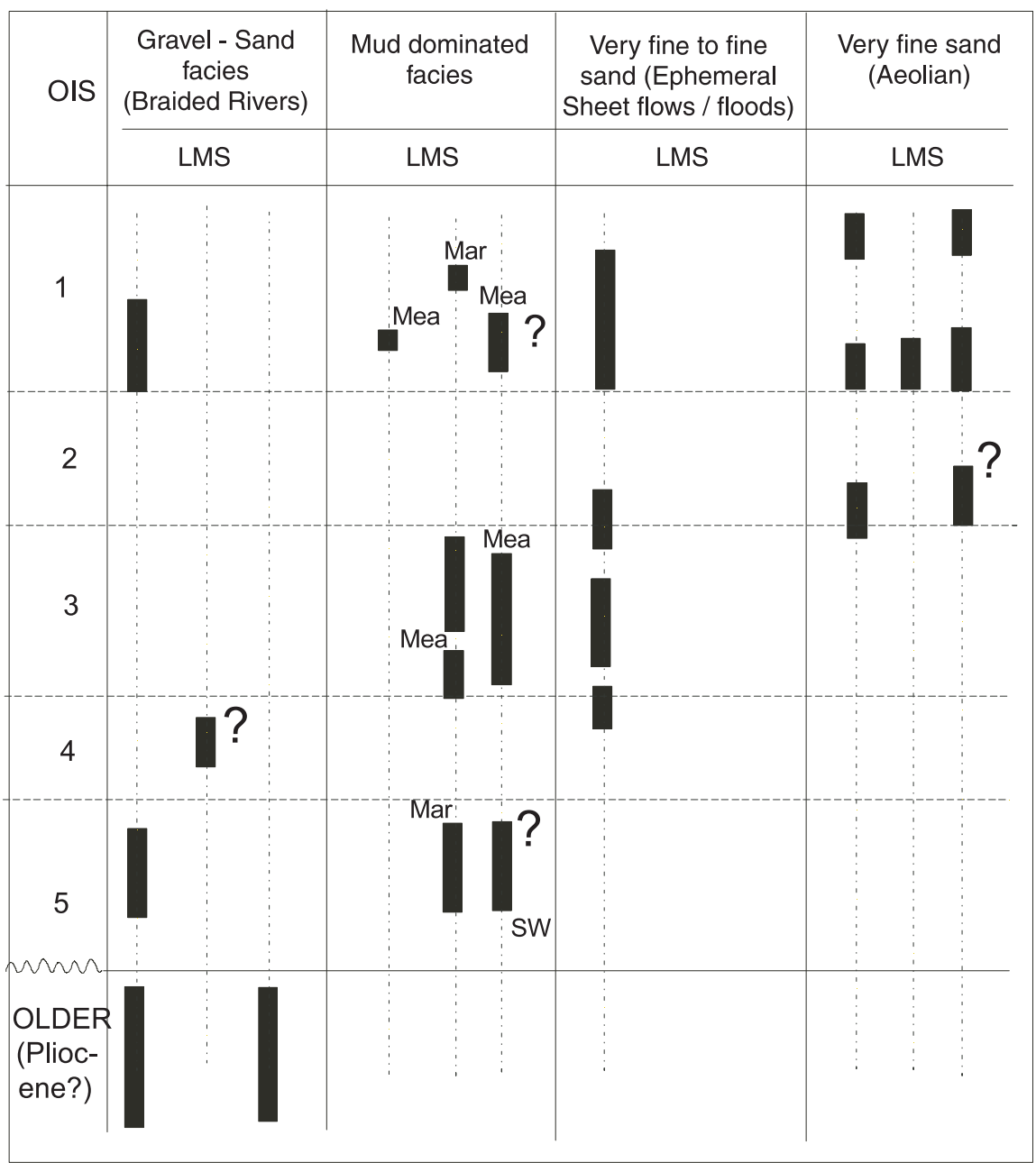

Figure 6. A schematic of lithofacies and depositional environments during different oxygen isotope stages (OIS 1 to OIS 5) in the Luni (L), Mahi (M), Sabarmati (S) basins. Mea - meandering streams, SW - seasonal wetland, Mar - marine. ? represents deposits where there are no direct ages, however, the chronologies have been mostly bracketed using the known age deposits (see Juyal et al 2000 and Jain and Tandon 2003a for the discussion).

have enough competence to carry gravel bedload. Incisions occurred during sustained wet phases perhaps as a result of reduction in the sediment supply/discharge ratio due to the vegetation effect (Vandenberghe 1995). A general absence of pedogenically-modified deposits during 11-14 ka suggests high aggradation rates. Pedogenic modification did not occur in these until after the stream incision during the early Holocene (Jain et al 2004).

\subsubsection{Mahi and Sabarmati basins}

A composite stratigraphy based on the studied deposits and the chronologies from the Mahi and Sabarmati basins is given in figure 8. The oldest OIS 5e deposits preserved in the more distal reaches of river Mahi are marine clays (Raika section, Juyal et al 2000). This phase is likely to be coeval with the phase of mud aggradation in the inland reaches of the Sabarmati river (Jain and
Tandon 2003a). The clay mineral indices (smectite/illite and smectite/chlorite) identify OIS 5e and OIS 1 to be comparable, and relatively the wettest periods in the region (Jain and Tandon 2003a) (table 3, figure 7). This was followed by gravel bedload braided stream deposits during the OIS 4 or OIS 4 - late OIS 5 transition in the Mahi basin (Juyal et al 2000; figure 8).

Subsequently during the wet OIS 3, there was a prolonged period of fluvial aggradation by mixed load meandering rivers (figure 8) and intermittent pedogenesis (regionally extensive red horizons). The two prolonged phases of aggradation viz., 52 to $44 \mathrm{ka}$ and 30 to $37 \mathrm{ka}$ in the Mahi basin (Juyal et al 2000) are consistent with the model predictions of Prell and Kutzbach (1987) and the palaeoenvironmental reconstruction in the Thar (figure 7). The landscape reddening occurred between 40 and $25 \mathrm{ka}$ in the Mahi basin (Juyal et al 2000) and 39 and $58 \mathrm{ka}$ in the Sabarmati basin (Tandon et al 1997). 


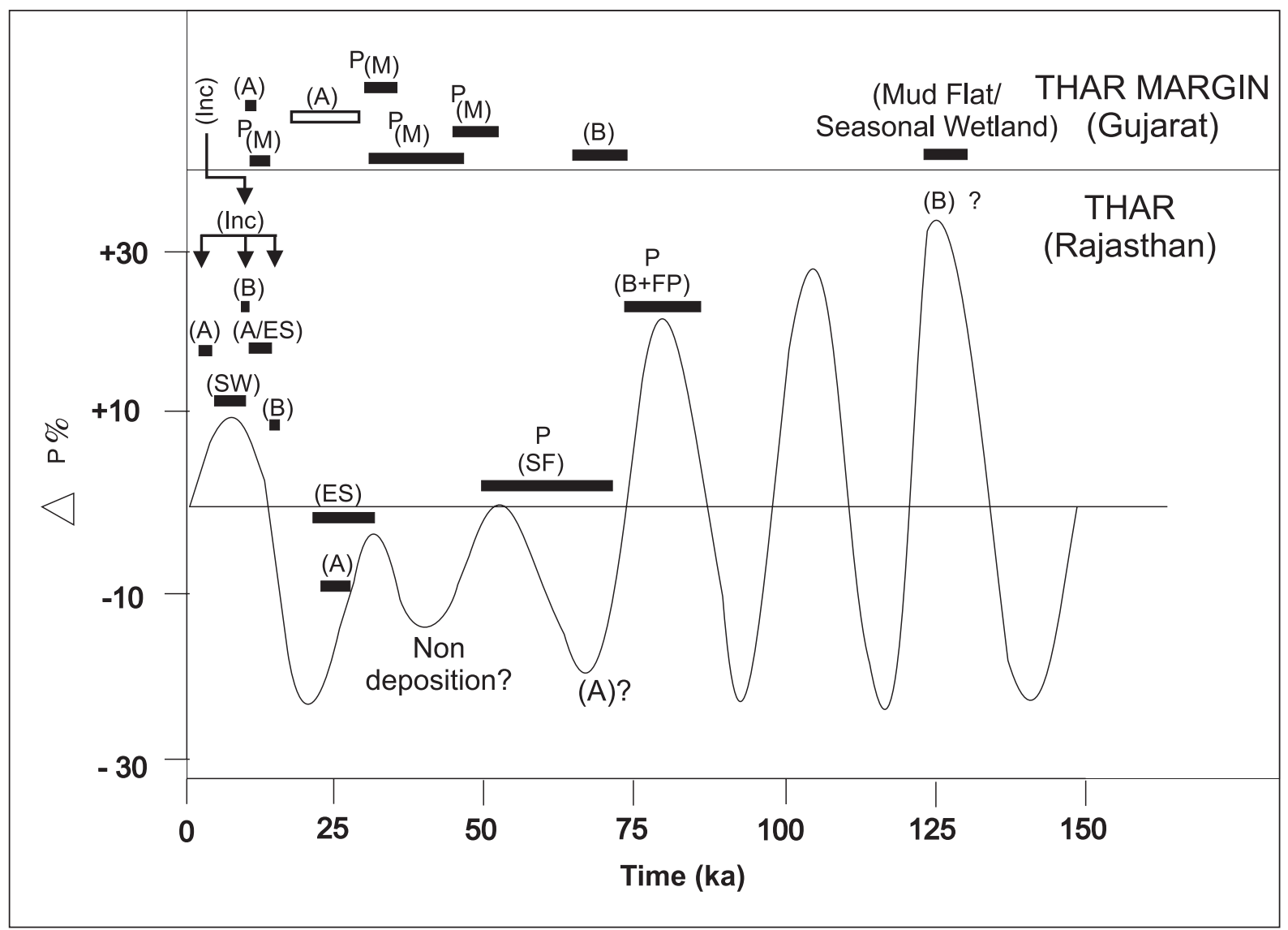

Figure 7. Fluvial patterns in the Thar and Gujarat alluvial plains superimposed on the model precipitation curve of Prell and Kutzbach (1987). $\mathbf{\Delta} \mathbf{P} \%$ - changes in precipitation with respect to the present. The changes are broadly synchronous in the two basins; however, a greater variety in palaeo-fluvial styles can be seen in the desert (Thar). The incisions are present during the wet phases in last 14 ka. $\mathbf{P}$ - Pedogenesis, SF - Sheet flood, SW - Sheetwash, ES - Ephemeral sand bed streams, B - Braided streams, FP - Floodplain, $\mathbf{M}$ - Meandering streams, A - Aeolian deposits, Inc. Incision. The hollow rectangle suggests the maximum possible age of the deposits based on stratigraphic age bracketing. Filled rectangles are based on chronological data from various sources summarised in the text. Figure reproduced from Jain and Tandon (2003b).

These diverse ages indicate that the reddening was not a single event but occurred syn-depositionally in the overbank deposits of these meandering river systems (Jain and Tandon 2003a). The clay mineral evidence also suggests this to have been a wet phase, although relatively less as compared to OIS 1 and OIS 5 (Jain and Tandon 2003a). Meandering streams during OIS 3 perhaps occurred as a result of increased vegetation, which resulted in a greater proportion of the fine-grained sediment load (produced due to weathering), bank stability, and relatively low sediment/discharge ratio as compared to the braided systems. The floodplains experienced intermittent pedogenesis reflected in regionally correlatable red horizons.

The latest OIS 3 and OIS 2 were characterised by fluvial inactivity and aeolian dunes (figures 7 and 8). There was a re-establishment of meandering streams during the 11-14 ka period (figures 7 and 8). It was soon followed by aeolian deposits, perhaps during the drier phases in the Late Glacial (figure 4). Both the Mahi and the Sabarmati rivers incised during the early Holocene perhaps as a response to climatic amelioration and reduced sediment availability.

\subsubsection{An inter-comparison of the late Quaternary alluvial deposits in semi-arid western Indian rivers}

A systematic variation of the fluvial pattern with the late Quaternary climate changes can be observed (figure 7). The phases of aggradation and incision occurred around the same times in the lower reaches of the three river basins. The apparent variations in fluvial styles, in the different regions, seem to reflect a continuum of processes within the semi-arid fluvial systems that is related through the precipitation gradient.

In Gujarat the more humid phases are represented by a meandering mode due to greater vegetation and discharge control (than the more arid counterparts), while, the wettest phases are 


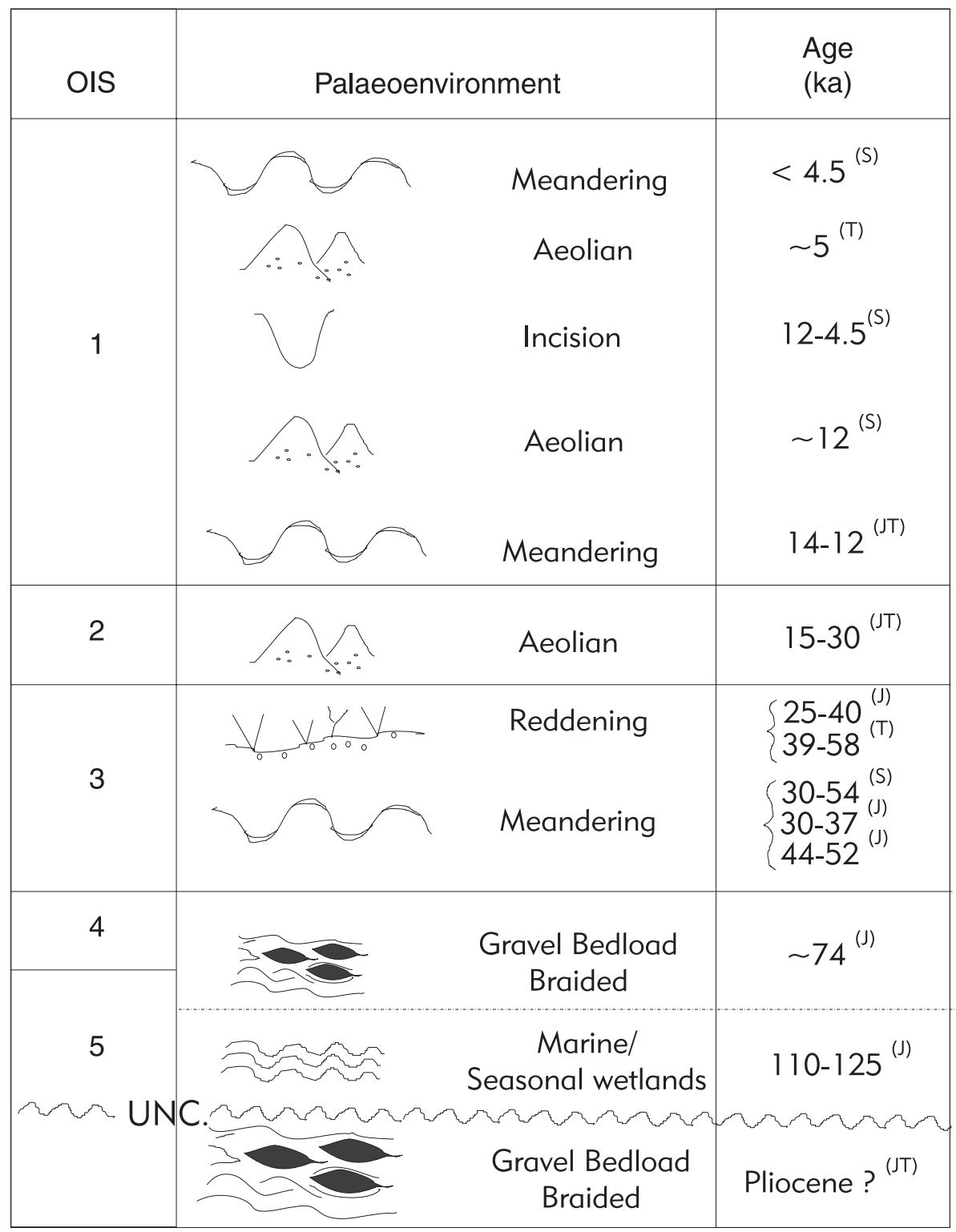

Figure 8. Fluvial stratigraphy in the Gujarat alluvial plains. Summarised from Tandon et al (1997) - (T), Juyal et al $(2000)-(\mathbf{J})$, Srivastava et al $(2001)-(\mathbf{S})$ and Jain and Tandon $(2003 \mathrm{a})-(\mathbf{J T})$. Figure reproduced from Jain and Tandon $(2003 b)$.

represented by stream incision (figures 7 and $8)$. The drier phases are represented by gravelbed braided streams due to decreased vegetation cover and increased sediment supply. The aeolian deposits are present during the arid phases in the desert proximal situations only.

On the other hand the gravel bedload or gravelsand bedload streams occur only during the wettest phases in the more arid Thar desert landscape. Progressive desiccation in the glacial period led to the formation of ephemeral sand bed rivers, perhaps due to vegetation decrease and an increased sediment supply of the sand sized grade (figure 7). Streams became largely inactive or defunct (due to blocking of the stream courses with aeolian sand) during the period of peak aridity. Jain and Tan- don (2003b) suggest that these differences in the response of the desert and desert-margin rivers reflect a continuum that is based on the climatic gradient across these regions.

An important difference between the desert and the desert-margin rivers is revealed in the fluvial response during the period of high frequency climatic fluctuations (late Glacial; figure 7). During the late Glacial, the Luni river in the Thar desert was very dynamic and showed frequent variations in fluvial styles: two episodes of gravel bedload braided streams, one episode of sand-bed ephemeral streams and one deposit of meandering streams, all followed by incision during the early Holocene. The coeval deposits in the Sabarmati, however, only show a meandering, floodplain 
dominated river. This suggests that the desert streams were more sensitive to climate change and may have very small response times and low geomorphic thresholds as compared to the desertmargin rivers.

The late Quaternary fluvial response in the lower reaches of the three semi-arid western Indian river basins was synchronous with those in other climatic regions of the world where base level, eustatic and tectonic effects were not significant. However, the fluvial environments that occurred during this time differed with those in the other regions of the world. These differences occurred on account of regional climate, and close linkages with other environments such as aeolian or glacial. For example, the channel patterns in the Indian semi arid rivers were governed by changes in the monsoon strength (and vegetation) and active aeolian processes, in comparison to the temperate rivers where meltwater pulses, glacial lake and/or vegetation played the key role. Parallels exist between some semiarid Indian, Australian and northwest European river systems in terms of occurrence of fluvio-aeolian environments during the OIS 2 and sensitivity to late Glacial climate changes (details in Jain and Tandon 2003b).

\section{Summary}

Comparison of late Quaternary alluvial successions in western India suggests that it is possible to define stratigraphic development in terms of fluvial response to high amplitude climatic changes. With the help of luminescence ages, it is possible to correlate the late Quaternary stratigraphic records in the Luni, Mahi and the Sabarmati basins. Purely cross-valley lithostratigraphic correlations are not viable since these basins responded differently to climate changes during the late Pleistocene; these changes resulted in different facies and facies associations in individual basins. The changes in fluvial pattern and the phases of incision can be explained by changes in discharge and sediment supply, which were forced by changes in monsoonal strength, and vegetation cover. There appears to be a continuum of processes between the desert and the desertmargin rivers that is linked through a precipitation gradient. The rivers in the Thar desert, in particular, were more sensitive to ambient climate and had lower geomorphic threshold as compared to the desert margin rivers; this is aptly demonstrated in the early OIS 1 record from the Luni basin.

There perhaps exists a hiatus between the deposition of the Pliocene type 1 and late-Pleistocene type 2 successions in the Thar desert: this gap is likely to be erosional in nature and is perhaps, due to an overall low accommodation space during the
Quaternary. Limited evidence suggests that a similar condition might exist for at least some exposed sections in the Thar margin such as Mahudi. This hypothesis implies the presence of a large discontinuity incorporating much of the Quaternary period in the exposed sections. It is, therefore, of prime importance to obtain accurate chronologies of the older deposits in order to understand the linkage between tectonics and sedimentation in the region.

\section{Acknowledgements}

We thank Dr. A K Singhvi, N Juyal (PRL, Ahmedabad); Dr. R P Dhir, Dr. A Kar and Dr. B K Sareen (CAZRI, Jodhpur); Dr. V N Bajpai, Ravindra, Arathi, Nikhil and Nivedita (Delhi University); Prof. S N Rajaguru and Dr. S Mishra (Deccan College, Pune); Prof. S S Merh, Dr. L S Chamyal, Dr. D M Maurya and Dr. J Mallik and Dr. A Khadkikar (M.S. University, Baroda) for support and helpful discussions.

\section{References}

Andrews J E, Singhvi A K, Kailath J A, Kuhn R, Dennis P F, Tandon S K and Dhir R P 1998 Do stable isotope data from calcrete record late Pleistocene monsoonal climate variation in the Thar desert of India?; Quat. Res. 50240 251

Arathi L 1996 Lithofacies, pedological and deformation characteristics of Quaternary continental sequences; Raika section, Mahi depression, Gujarat, M Sc Dissertation, University of Delhi

Bajpai V N, Roy T K S and Tandon S K 2001 Subsurface sediment accumulation patterns and their relationships with tectonic lineaments in the semi-arid Luni river basin, Rajasthan, Western India; J. Arid Environments 48 603621

Baskaran M 1985 Radiometric mineralogical and trace elemental studies of the Saurashtra Quaternary carbonate deposits: implications to their age and origin; Unpublished $\mathrm{Ph} \mathrm{D}$ thesis, Gujarat, Ahmedabad

Blum M D and Törnqvist T E 2000 Fluvial responses to climate and sea-level change: a review and look forward; Sedimentology $472-48$

Bryson R A and Swain A M 1981 Holocene variations of monsoon rainfall in Rajasthan; Quat. Res. 16 135-145

Chamyal L S and Merh S S 1992 Sequence stratigraphy of the surface Quaternary deposits in the semi-arid basins of Gujarat; Man and Environment 17 33-40

Chamyal L S and Merh S S 1995 The Quaternary formations of Gujarat, Mem Geol. Soc. India, 32 246-257

Chamyal L S, Maurya D M and Rachna R 2003 Fluvial systems of the drylands of western India: a synthesis of late Quaternary environmental and tectonic changes; Quarternary International 104 69-86

Chandra P K and Chaudhury L R 1969 Stratigraphy of the Cambay basin; Bull. Oil. Nat. Gas Comm., Dehradun 6(2) $37-50$

DeCelles P G, Gehrels G E, Quade J and Ojha T P 1998 Eocene-early Miocene foreland basin development and the history of Himalayan thrusting, western and central Nepal; Tectonics 17 741-765 
Enzel Y, Ely L L, Mishra S, Ramesh R, Amit R, Lazar B, Rajguru S N, Baker V R and Sandler A 1999 High-resolution Holocene environmental changes in the Thar desert, north western India; Science 284 124128

Foote R B 1898 Geology of Baroda State (Baroda State: Govt Press)

Gibling M R, Tandon S K, Sinha R and Jain M 2004 Modern interfluves and their expression in the late Quaternary record of the southern Gangetic plains (under revision)

Goudie A, Allchin B and Hegde K T M 1973 The former extention of the great Indian sand desert; Geol. J. 139 $243-257$

Hashimi N H, Nigam R, Nair R R and Rajagopalan G 1995 Holocene sea level fluctuations on Western Indian Continental Margin: An Update; J. Geol. Soc. India 46 157162

Jain M 2000 Stratigraphic development of some exposed Quaternary alluvial sequences in the Thar and its margins: Fluvial response to climate change, Western India; Unpublished Ph D thesis, University of Delhi, India

Jain M and Singhvi A K 2001 Limits to depletion of blue-green light stimulated luminescence in feldspars: Implications for quartz dating; Radiation Measurements 33 883-892

Jain M and Tandon S K 2001 Palaeoclimatic reconstruction using $\delta^{13} \mathrm{C}$ and $\delta^{18} \mathrm{O}$ composition of pedogenic calcretes in some Quaternary alluvial palaeosols, Thar desert, western India; Abstract volume, $7^{\text {th }}$ Int. Conf. on Fluvial Sedimentology, 139

Jain M, and Tandon S K 2003a Quaternary alluvial stratigraphic development in a desert margin river, western India; Current Science 84(8) 1048-1055

Jain M and Tandon S K 2003b The fluvial response to the Late Quaternary climate changes, western India; Quat. Sci. Reviews 22 2223-2235

Jain M, Bøtter-Jensen L and Singhvi A K 2003a Dose evaluation using multiple-aliquot quartz OSL: test of methods and a new protocol for improved accuracy and precision; Radiation Measurements 37 67-80

Jain M, Tandon S K, Singhvi A K Mishra S and Bhatt S C 2004 Quaternary alluvial stratigraphic development in a desert setting: a case study from Luni river basin. Western India In: Fluvial Sedimentology VII (Eds Blum M, and Marriott S), International Association of Sedimentologists, Special Publication (in press)

Jain M, Tandon S K, Bhatt S C, Singhvi A K and Mishra S 1999 Alluvial and aeolian sequences along the river Luni, Barmer district: Physical stratigraphy and feasibility of luminescence chronology methods In: Vedic Saraswati (Eds Radhakrishna, B P and Merh, S S); Geol. Soc. India Mem, 42 273-295

Jain M, Woodcock N H and Tandon S K 1998 Neotectonics of Western India: evidence from late Quaternary fluvial sequences, Mahi river, Gujarat; J. Geol. Soc. London 155 897-901

Juyal N, Raj R, Maurya D M, Chamyal L S and Singhvi A K 2000 Chronology of late Pleistocene environmental changes in the lower Mahi basin, western India; J. Quat. Sci. 15 501-508

Kar A, Singhvi A K, Rajguru S N, Juyal N, Thomas J V, Banerjee D and Dhir R P 2000 Reconstruction of the late Quaternary environments of the lower Luni plains, Thar Desert, India; J. Quat. Sci. 15 1-8

Khadkikar A S, Chamyal L S, Malik J N, Maurya D M and Merh S S 1996 Arid-humid cycles over the last $350 \mathrm{ka}$ : Evidence from Mahi river basin, Western India; J. Geol. Soc. of India 46 289-299
Maurya D M, Chamyal L S and Merh S S 1995 Tectonic evolution of the Central Gujarat Plain, Western India; Current Science 69 610-613

Maurya D M, Malik J N, Rachna R and Chamyal L S 1997a Soft- sediment deformation in the Quaternary sediments of the Lower Mahi Basin, Western India; Current Science 72 519-522

Maurya D M, Malik J N, Rachna R and Chamyal, L S 1997b The Holocene valley fill terrace on the lower Mahi valley, Gujarat Alluvial Plains; Current Science 73 539-542

Maurya D M, Rachna R Chamyal L S 2000 History of tectonic evolution of Gujarat alluvial plains, western India during Quaternary: a review; J. Geol. Soc. India 55343 366

Merh S S and Chamyal L S 1997 Quaternary Geology of Gujarat Alluvial Plains; Proceedings of Indian National Science Academy 63 1-98

Merh S S 1995 Geology of Gujarat; Memoir of Geol. Soc. of India $1-220$

Mishra S, Jain M, Tandon S K, Singhvi A K, Joglekar P P, Bhatt S C, Kshirsagar A, Naik S and Mukerjee AD 1999 Prehistoric cultures and late Quaternary environments in the Luni basin around Balotra; Man and Environment 24 38-49

Pandarinath K, Prasad S, Gupta S K 1999a A 75 ka Record of Palaeoclimatic changes Inferred from Crystallinity of Illite from Nal Sarovar, Western India; J. Geol. Soc. of India 54 515-522

Pandarinath K, Prasad S, Deshpande R D, Gupta S K 1999b late Quaternary sediments from Nal Sarovar, Gujarat, India: Distribution and provenance; Earth Planet Sci. 108 107-116

Pant R K and Chamyal L S 1990 Quaternary sedimentation pattern and terrain evaluation in Mahi river basin, Gujarat, India; Proceedings of Indian National Science Academy 56 501-511

Plint A G, Hart B S and Donaldson W S 1993 Lithospheric flexure as a control on stratal geometry and facies distribution in Upper Cretaceous rocks of the Alberta foreland basin; Basin Research 5 69-77

Prasad S and Gupta S K 1999a Luminescence dating of a $54 \mathrm{~m}$ long core from Nal region, western India - implications; Quat. Sci. Reviews 18 1495-1505

Prasad S and Gupta S K 1999b Holocene climate fluctuations in monsoonal Asia, Arabia and Africa - Review and possible causes In: Modern and Ancient Lakes (Eds Pitman J K, Carroll A R ) Utah Geological Association Guidebook 26 261-275

Prasad S and Gupta S K 1999c Role of eustasy, climate and tectonics in late Quaternary evolution of Nal-Cambay region, NW India; Zeitschrift für Geomorphologie 43 483504

Prasad S, Kusumgar S, and Gupta S K 1997 A mid- to late Holocene record of paleoclimatic changes from $\mathrm{Nal}$ Sarovar: a palaeodesert margin lake in western India; J. Quat. Sci. 12 153-159

Prasad S, Pandarinath K and Gupta S K 1998 Geomorphology, tectonism and sedimentation in the Nal region, western India; Geomorphology 25 207-233

Prell W L, Kutzbach J E 1987 Monsoon variability over the past 150,000 years; J. Geophysical Research 928411 8425

Rachna R, Maurya D M and Chamyal L S 1998 Late Quaternary sea level changes in Western India: Evidence from the lower Mahi valley; Current Science 74 910914

Rachna R, Maurya D M, Chamyal L S 1999a Tectonic geomorphology of the Mahi river basin, Western India; J. Geol. Soc. India $\mathbf{5 4} 387-398$ 
Rachna R, Maurya D M, Chamyal L S 1999b Tectonic control on distribution and evolution of ravines in the Lower Mahi Valley, Gujarat; J. Geol. Soc. India 56 669674

Retallack G J 1986 Fossil soils as grounds for interpreting long-term controls on ancient rivers; J. Sedimentary Research $\mathbf{5 6}$ 1-18

Sankalia H D 1945 Investigation into the pre-historic archaeology of Gujarat, (Baroda: Baroda State Press)

Sareen B K 1992 Geomorphology, neotectonics, late Quaternary sedimentation patterns and TL chronology of the semi-arid Sabarmati basin, Gujarat Alluvial plain, India, $\mathrm{Ph} \mathrm{D}$ Thesis, University of Delhi (unpublished)

Sareen B K, Tandon S K and Bhola A M 1993 Slope deviatoy alignment, stream network and lineament orientation of the Sabarmati river system: neotectonic activity in the mid-Late Quaternary; Current Science 64 827836

Sharma K D, Vangani N S and Choudhari J S 1984 Sediment transport characteristics of the desert streams in India; J. Hydrology 67 261-272

Singh G, Joshi R D, Chopra S K and Singh A B 1974 late Quaternary history of vegetation and climate of the Rajasthan desert, India; Philosophical Transactions of the Royal Society 267B 467-501

Sohoni P S and Malik J N 1998 Remnants of large magnitude earthquakes: evidences from the Great Rann sediments, Kachchh, western India; Current Science $\mathbf{7 4}$ 985-989
Sridhar V and Chamyal L S 1996 Debris and sheet flow dominated gravels in the Sabarmati basin of western India; Zeitschrift für Geomorphologie 103 243-248

Srivastava P, Juyal J, Singhvi A K, Wasson R J and Bateman M D 2001 Luminescence chronology of river adjustment and incision of Quaternary sediments in the alluvial plain of the Sabarmati river, North Gujarat, India; Geomorphology 36 217-229

Swain A M, Kutzbach J E and Hastenrath S, 1983 Monsoon climate of Rajasthan for the Holocene; Estimates of precipitation based on pollen and lake levels; Quat. Research $191-17$

Tandon S K, Sareen B K, Rao M S and Singhvi A K 1997 Aggradation history and luminescence chronology of Late Quaternary semi-arid sequences of the Sabarmati basin, Gujarat, western India; Palaeogeography Palaeoclimatology Palaeoecology 128 339-357

Tandon S K, Jain M and Singhvi A K 1999 Comparative development of mid- to late Quaternary fluvial and fluvioaeolian stratigraphy in the Luni, Sabarmati and Mahi river basins of western India; Gondwana Geological Magazine Special Volume 4 1-16

Vandenberghe J 1995 Timescales, climate and river development; Quat. Sci. Reviews 14 631-638

Wasson R J, Rajaguru S N, Misra V N, Agarwal D P, Dhir R P and Singhvi A K 1983 late Quaternary stratigraphy and palaeoclimatology of the Thar dune field; Z. Geomorphology N. F. 45 117-151

Zeuner F E 1950 Stone age Pleistocene chronology of Gujarat; Deccan College Monograph 646 pp 